\title{
ガスエンジンと潤滑 $(1)^{*}$ \\ -今まで分からなかったガスエンジン油の全てがわかる
}

\author{
鍵 渡 德 彦** \\ Gas Engine and Its Lubrication \\ -Unresolved Phenomena in Lubrication and Their Clarifications
}

花 島

脩

By Norihiko Kagiwata, Osamu Hanashima

\begin{abstract}
First successful gas engine was the Lenoir atmosphere gas engine, which was invented around 1860 . Since this engine did not use compression, thermal efficiency was very low. Ever since gas engines have had a very long history. However, the authors did not find any papers, which mention the reasons why nitration, deposit formation in combustion chamber and others occur in gas engine although diesel engine does not have any problems in these areas. In this article, those related reasons and also compilation of quality and performance requirements for gas engine oils for better understanding the gas engines were described.
\end{abstract}

\section{1.はじめに}

歷史上初めてガスエンジンが成功裏に運転されたの は1860年頃であった1)。このガスエンジンは過給され ていなかったため熱効率は非常に低かった。これ以来, ガスエンジンは非常に長い歴史を持っている. それに も拘わらずガスエンジンに特有な潤滑上の諸現象に関 して，何故そのような現象が生じるのかその原因の根 源について述べた文献は，著者が探す限り見当たらな かった。

上述の諸現象とは，ディーゼルエンジンでは問題に なることの少なかった潤滑油のナイトレーションや然 焼室内堆積物が生じやすいこと。また，軸受オーバレ イ寿命は，ガスエンジンの方が回転数が若干低いとい う負の要因があるとしても，残渣を若干含むA重油使 用機関に比べれば有意差をもって長くなるはずである が，実際にはA重油使用機関の場合と同等或いは短い 場合が存在すること，などがあげられる.

そこで，著者はディーゼルエンジン油では問題にな らない上記の潤滑上の諸現象が何故にガスエンジン油 では問題になるのか，その原因の根源を探ることを試 みると共に，上り理解を深めるために，ガスエンジン 油に対する性能上や品質上の要求項目等も併せて調べ たのでそれらについても報告する.

*原稿受付 平成 18 年 10 月 5 日

***昭和シェル石油株(神奈川県愛甲郡愛川町中津 4052-2)

****Shell Marine Products(川崎市向原 3-19-13)
尚, 本稿ではガスエンジンの燃料は, 主として天然 ガス(主成分メタン)を対象とした。

\section{2. ガスエンジンの種類}

ガスエンジンは種々の可燃性ガスを燃料とする内燃 機関で，ガスはディーゼルエンジンの燃料のように自 然着火しないので，何等かの着火源を必要とする. ガ スエンジンは着火方法や燃焼室のタイプにより次の四 つに分類できる ${ }^{2)}$.

(1) 直接火花点火方式 (ストイキ) (Spark-ignition gas engines)

理論空然比の下で点火プラグによって着火させる. 排出ガス中のNOxが高く, 三元触媒で対応する.

(2) パイロット油直接圧縮点火方式(デュアルフューエ ル, Gas-diesel engines)

燃焼室内に約 $10 \%$ の石油系液体燃料油を直接噴射し て, ディーゼルエンジンと同様に自然着火させる. 排 出ガス中のNOxが高く現在の規制には合わない．この 場合，全量油焚きが可能である.

(3) 予燃焼室火花点火方式（リーンバーン）

予燃焼室のガスに点火プラグで着火させて, 主燃焼 室中の希薄混合気のガスに着火させる. 排出ガス中の NOxは低い，発電効率が向上できる.

(4) 予燃焼室パイロット油着火方式(マイクロパイロッ

ト, Dual-fuel engines)

この着火方式が最も新しい，予燃焼室中に約 $1 \%$ の石 
油系液体燃料油を噴射弁で噴霧して着火させ，主燃焼 室の希薄混合気のガスに着火させる. 排出ガス中の Noxは低い.この種の高効率ガス機関の出力および発 電効率レベルは更に向上し，ディーゼルエンジンのレ ベルと同一になってきた. 高BMEPにはマイクロパイロ ット着火燃焼技術が, 発電効率向上には後述のミラー サイクルが寄与している2゙.

尚，ミラーサイクルのガスエンジンは一般に圧縮着 火させるには充分な圧縮温度に達しないため, 補助手 段としてエンジン起動時に起動用点火プラグ(グロー 或いは電気火花)により確実に油燃料に着火させる.

結論として, ガスエンジンを高出力高効率化するた めには，予燃焼室パイロット油着火方式が必須である. 表 $1^{2}$ に従来の方法との比較を示す.

表 1 着火エネルギーの比較 ${ }^{2)}$

\begin{tabular}{|c|c|c|}
\hline 点火方式 & 火花点火 & 油着火 \\
\hline タイプ & \multicolumn{2}{|c|}{ 予燃焼室，希薄燃焼 } \\
\hline 点火エネルギー & 1 & 数千倍 \\
\hline $\begin{array}{c}\text { 低発熱量ガス } \\
\text { 安定燃焼 }\end{array}$ & $\begin{array}{c}\text { 最低 } \\
20 \mathrm{MJ} / \mathrm{Nm}^{3}\end{array}$ & $\begin{array}{c}\text { 最低 } \\
5 \mathrm{MJ} / \mathrm{Nm}^{3}\end{array}$ \\
\hline 点火源の耐久性 & $2,000 \mathrm{~h} \max$ & $4,000 \sim 8,000 \mathrm{~h}$ \\
\hline $\begin{array}{c}\text { 正味平均有効圧 } \\
\text { (B. M. E. P.) }\end{array}$ & $1.5 \sim 1.8(2.0) \mathrm{MPa}$ & $2.0 \sim 2.2(2.5) \mathrm{MPa}$ \\
\hline
\end{tabular}

\section{3. ガスエンジンの用途とガスの種類}

\section{1. ガスエンジンの用途ガスエンジンは種々な} 用途に広く使用されている. 例として, ホテル, 病院, 工場(農業を含む), 店舗等で使用されるCHP (Combined heat/power generation, 時折, 温室に於いて $\mathrm{CO}_{2}$ を活 用する場合もある) やGHP (Gas engine driven heat pump), 自家発電所, 原油やガス生産現場, 下水処理 場, 埋立て地, ごみ処理場, LNG/LPG タンカー等であ る. 上記の用途に応じて種々のガスが使用される.

\section{2. ガスの種類ガスの種類を下記に記す.}

(1) 天然に産出するガス (天然ガス)

天然ガスは，広い意味では天然に産するガスの総称 で, ガス田・油田のガス, 火山ガス, 温泉ガス, 炭酸 泉の炭酸ガス等を全て含む. その構成成分は, メタン 等の炭化水素類の他に, $\mathrm{CO}_{2}, \mathrm{~N}_{2}, \mathrm{H}_{2} \mathrm{~S}$ 等がある.

(2) 製造ガス

(a)化学工業の過程で副生するガス 高炉ガス，石油精製や石油化学の才フガス及び夜化 石油ガス等がある.

(b) 固体, 液体然料をガス化したガス

石炭ガス, 発生炬ガス, 原油熱分解ガス, 接触分解
ガス, ナフサ改質ガス，LPG改質ガス，オフガス改質 ガス等がある.

(c)都市ガス (town gas)

ガスエンジンで最も多用されているガスは, 都市ガ スである．都市ガスは各種ガスを一定の品質を保つよ うに混合し，導管で家庭や工場に供給するガスである. 都市ガスの区分を表 $2^{3)}$ に示す。都市ガスは当初, ガス事業法の昭和46年(1971年)に制定された「ガス用 品関係法令」(通産省告示第306号)により，13種のガ スグループに区分されていたが，平成7年(1995年)よ りガス事業法の「ガス用品の技術上の基準に関する省 令」の「別表三の (備考)」に $\mathrm{L}_{1}, \mathrm{~L}_{2}, \mathrm{~L}_{3}$ グループがで き，現在7種類のガスグループが規定されている3). 都市ガスは，これを供給している都市ガス会社毎にガ スの種類が異なっており，ガス事業法ではこれらの都 市ガスを比重, 熱量, 燃焼速度の違いにより表2のよ うに区分している，尚，日本国内には235のガス事業 者(平成13年10月現在)が存在する ${ }^{3)}$.

表 2 都市ガスの区分 ${ }^{3)}$

\begin{tabular}{|c|c|c|}
\hline $\begin{array}{c}\text { ガスグループ } \\
\text { (燃焼性種別) }\end{array}$ & $\begin{array}{c}\text { ウォッベ指数 } \\
\text { (Wobbe Index) }\end{array}$ & $\begin{array}{c}\text { 燃焼速度 } \\
(\mathrm{MCP})\end{array}$ \\
\hline $13 \mathrm{~A}$ & $52.7 \sim 57.8$ & $35.0 \sim 47.0$ \\
\hline $12 \mathrm{~A}$ & $49.2 \sim 53.8$ & $34.0 \sim 47.0$ \\
\hline $6 \mathrm{~A}$ & $24.5 \sim 28.2$ & $34.0 \sim 45.0$ \\
\hline $\mathrm{L}_{1}(6 \mathrm{~B}, 6 \mathrm{C}, 7 \mathrm{C})$ & $23.7 \sim 28.9$ & $42.5 \sim 78.0$ \\
\hline $5 \mathrm{C}$ & $21.4 \sim 24.7$ & $42.0 \sim 68.0$ \\
\hline $\mathrm{L}_{2}(5 \mathrm{~A}, 5 \mathrm{~B}, 5 \mathrm{AN})$ & $19.0 \sim 22.6$ & $29.0 \sim 54.0$ \\
\hline $\mathrm{L}_{3}(4 \mathrm{~A}, 4 \mathrm{~B}, 4 \mathrm{C})$ & $16.2 \sim 18.6$ & $35.0 \sim 64.0$ \\
\hline
\end{tabular}

表2中のガスグループの識別記号の数字, 即ち, 例 として13Aの数字「13」は，ガスの発熱量のレベルを 意味し, 数字が大きくなるに従い発熱量は増加する. 具体的には，ガスの総発熱量を過去使用されていた単 位 $\left(\mathrm{kcal} / \mathrm{Nm}^{3}\right)$ で表したウォッべ指数の平均值を 1,000 で割って，小数点以下を切り捨てたものにほぼ該当す る3). 同ガスグループの識別記号のアルファベット， 即ち, 例として13Aの「A」は, 燃焼速度のレベルを意 味し,「A」は燃焼速度が遅く $(38-40 \mathrm{~cm} / \mathrm{sec})$,「B」は 燃焼速度が中位 $(47-65 \mathrm{~cm} / \mathrm{sec})$,「C」は燃焼速度が速 い(64-68cm/sec). 従って, ガスグループ「13A」のガ スは発熱量が高く，燃焼速度が遅いガスである.

表2中のウォッベ指数は, 総発熱量 $\left(\mathrm{MJ} / \mathrm{Nm}^{3}\right)$ をガス の空気に対する比重の平方根で割った值で， ウォッベ 指数が同じなら同一圧力で同一のノズルから単位時間 に供給される熱量は同じとなる. ウォッべ指数は, ガ ス器具での燃料ガス互換性の判断指標となる. 
表2中の燃焼速度 (MCP) は, 燃料ガスの組成により決 まり，計算式により得られる值である，MCPは，ガス の最大燃焼速度に近似するものとして定められたもの で, Maximum Combustion Potentialの略である゙3.

ウォッべ指数及び燃焼速度 (MCP) の算出法は, 過去, ガス事業法の「通産省告示第634号」に規定されてい たが，現在では，ガス事業法の「ガス用品の技術上の 基準に関する省令」の「別表三の(備考)」中に規定さ れている ${ }^{3)}$. 更に, ウォッべ指数及び然焼速度 (MCP) の算出に必要な総発熱量その他は，日本工業規格JISK2301 (燃料ガス及び天然ガス - 分析・試験法) 中に 規定されている旨，ガス事業法の「ガスの熱量及び然 焼性の測定方法を定める件」（昭和45年10月9日，通産 省告示第634号) 中に記述されている3).

次に, 都市ガスの変遷に関して触れると, 1940年代 後半迄では石炭を原料とするガスが主流であったが, 1950年代前半〜1960年代後半には，LPGやナフサ等の 石油系ガス (6A, 6Bガス)に変わり，更に，1970年代か らはクリーンな天然ガス系ガス (13A)への転換がなさ れた．尚，2010年には日本国内の都市ガスの全てが 13A(12A)に統一される予定である ${ }^{4)}$.

次に，都市ガス13Aの組成の代表例を表 $3^{4}$ に示寸.

表 3 都市ガス $13 \mathrm{~A}$ の組成の代表例 4)

\begin{tabular}{|c|c|c|c|}
\hline 項 目 & 組 & $\begin{array}{c}\text { 天然ガス } \\
13 \mathrm{~A} \\
\end{array}$ & $\begin{array}{c}\text { プロパンエアー } \\
13 \mathrm{~A} \\
\end{array}$ \\
\hline \multirow{5}{*}{ 組 成 } & メタン (vol\%) & 89.6 & 0 \\
\hline & エタン (vol\%) & 5.62 & 0 \\
\hline & プロパン(vol\%) & 3. 43 & 57.7 \\
\hline & ブタン (vol\%) & 1.35 & 3 \\
\hline & 空気 (vol\%) & 0 & 39.3 \\
\hline \multicolumn{2}{|c|}{ 総発熱量 $\left(\mathrm{MJ} / \mathrm{Nm}^{3}\right)$} & 45.0 & 62.3 \\
\hline \multicolumn{2}{|l|}{ 比重 } & 0.64 & 1.35 \\
\hline \multicolumn{2}{|c|}{ ウオッべ指数 } & 56.4 & 53.7 \\
\hline \multicolumn{2}{|c|}{ 燃焼速度 (MCP) } & 37.0 & 40.8 \\
\hline \multicolumn{2}{|c|}{ ガスグループ } & \multicolumn{2}{|c|}{$13 \mathrm{~A}$} \\
\hline \multicolumn{2}{|c|}{ メタン価 } & 68.8 & 33.2 \\
\hline \multicolumn{4}{|c|}{$\begin{array}{l}\text { 天然ガス } 13 A \text { 組成: 東京ガス(株)HP } \\
\text { プロパンエアー組成：日本ガス協会「PA-13A 導入にあたって } \\
\text { の保安技術資料」より抜粋 } \\
\text { メタン価資料 : Evaluation of Antiknocking Property of } \\
\text { Gaseous Fuels by Means of Methane Number and its } \\
\text { Practical Application to Gas Engines, ASME 72-DGP-4 }\end{array}$} \\
\hline
\end{tabular}

(3)バイオガス (biogas)

バイオガスに関して触れる前にバイオマス (biomass)について述べる. バイオマスの意味は，2種 類ある．第一に，生物体量または生物量を意味する. 即ち, ある時点に任意の空間内に存在する特定の生物 群の量を質量やエネルギー量で表した乾燥質量を用い
ることが多いが，湿質量や時には生物体の主要な構成 成分である炭素や窒素で表すこともある5). 次に第二 の意味は，1973年の石油危機以降に使われ始めた意味 であるが，植物を中心とする生物を原料としてエネル ギーを生産することが考えられており，その原料をバ イオマスと呼称する ${ }^{6}$. 本稿では, 後者に関して触れ る.

バイオマスは直接然焼させて熱源として活用，或い はガスや液体燃料の原料として使用出来る. バイオマ スは，太陽熱，太陽電池，風力，水力，地熱等と同様 に再生可能エネルギー(renewable energy) 資源の一つ であり，光合成によって太陽エネルギーを有機化合物 である炭水化物に転換して，それをエネルギーとして 活用するので，間接的に太陽エネルギーを活用してい ると言える.

バイオマスは，1990年の時点で世界で消費するエネ ルギーの約14\%程度を賄っているに過ぎないが，その 潜在する総量は，世界で消費するエネルギーの総量を 遥かに上回っている7.

バイオマスとは，太陽エネルギーによる光合成によ って作られた植物類，およびそれによってもたらされ る例えば，森林の樹木，農作物の残渣物，畜産の残渣 物, 即ち, 牛や豚の糞や尿, 鶏粪, 家庭, 都市ごみや 下水中の有機物質を総称したものである8).

現時点の環境上の最重要課題は, 地球温暖化に負の 影響を与える大気中の $\mathrm{CO}_{2}$ 量であろう。バイオマスは, $\mathrm{CO}_{2}$ バランスが維持できるレベルで生産される限り， バイオマスの処理・加工や燃焼時に発生する $\mathrm{CO}_{2}$ 量と 光合成のプロセス時に吸収する $\mathrm{CO}_{2}$ 量はバランスする. 即ち, バイオマスの生産時や輸送時に使用寸る石油系 液体燃料油から発生する $\mathrm{CO}_{2}$ 量を除外すると, バイオ マスを然料として使用した場合，大気中の $\mathrm{CO}_{2}$ 量を増 加させない.

上記に述べたバイオマスを熱化学的変換或いは生物 化学的変換によって得た燃料ガスのバイオガス, 即ち, メタンを得ることが出来る.

バイオガスには，次の様な種類がある.

(a)消化ガス (digester gas)

畜産粪尿をメタン発酵させて，バイオガス(メタン 成分：60-65\%) を回収して燃料として使用する. メ夕 ン発酵は, 酸素のない状態(嫌気性環境)でメタン細菌 の作用により翼尿中に含まれる有機物を分解して, メ タンガスと炭酸ガスに転換する方法である. メタン発 酵は, 発酔槽を $35^{\circ} \mathrm{C}$ 前後に保持寸る中温発酵と $55^{\circ} \mathrm{C}$ 前 後に保持する高温発酵がある.

(b) 下水処理の余剩污泥 (活性污泥)のメタン発酵に よるバイオガス

(c) 埋立地で発生するメタンガス (landfill gas)を 
採取し活用する

実例として，東京都では東京湾内の埋立地で発生す るメタンガスを採取してガスエンジンを駆動し $960 \mathrm{~kW}$ 発電を行っている.

この項の纏めとして，各種ガスの性状例を表 $4^{9)}$ に 示す.

\section{参考文献}

1) Shell International Petroleum Co. Limited, An outline history of the oil engine and its lubrication, 1961, page 16

2）後藤悟，高効率ガス機関の開発-NOx，SOx， GHG， 全てに優しい高効率ガス機関，日本内燃機関連合会講 演会，2006年3月 16 日
3）和久井幹雄氏 (東京ガス) から筆者宛e-mai1，2006 年4月17日

4）斉藤準(東京ガス)，ガス燃料の特徵と使い方一日 本で使用されている13Aとは一，日本内燃機関連合会 講演会，2006年3月16日

5）平凡社，大百科事典，1985年，第11の頁877

6）(株ティビーエス・ブリタニカ，ブリタニカ国際大 百科事典，1993年，第16の頁 66

7) Shell, Shell Briefing Service, 1994, Renewable energy, page $1 \& 8$

8) ibid, page 3

9) CIMAC No.19 (2000), Recommendations for the lubrication of gas engines, page 2

表 4 ガスエンジン用燃料とその性状例 ${ }^{9)}$

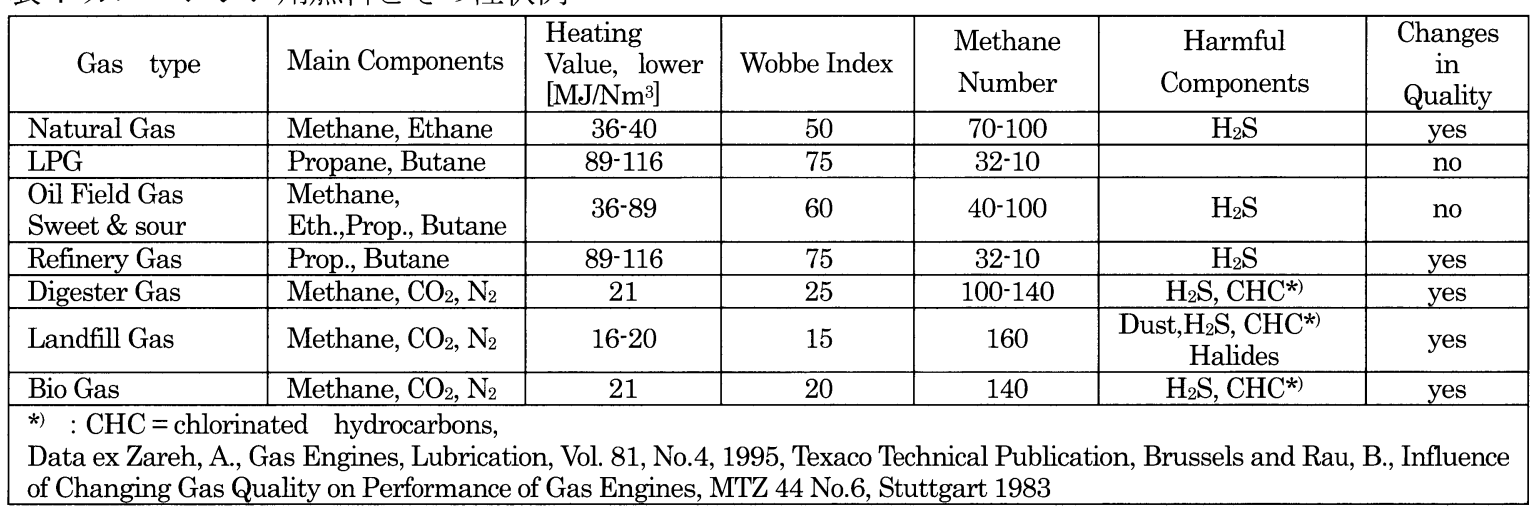

